\title{
Photoautotrophic metabolism of Caulerpa taxifolia (Chlorophyta) in the NW Mediterranean
}

\author{
John R. M. Chisholm ${ }^{1, *}$, Jean M. Jaubert ${ }^{1,2}$ \\ ${ }^{1}$ Observatoire Océanologique Européen, Centre Scientifique de Monaco, Avenue Saint-Martin, MC-98000, Principality of Monaco \\ ${ }^{2}$ Université de Nice-Sophia Antipolis, Laboratoire d'Écologie Expérimentale, Campus Valrose, F-06108 Nice Cédex 02, France
}

\begin{abstract}
Oxygen production and consumption by the green alga Caulerpa taxifolia was measured in the NW Mediterranean at Monaco using a submersible respirometer. Photosynthesis versus irradiance $(P-I)$ curves were constructed for populations at depths of 10,15 and $25 \mathrm{~m}$ in summer and $10 \mathrm{~m}$ in winter. C. taxifolla did not exhibit many of the photoadaptive responses to bathymetric changes in irradiance that have been reported in other algae. The initıal slope of the $P$ - $I$ curve $(\alpha)$ was inversely proportionate to depth; the irradiance required for respiratory compensation $\left(I_{c}\right)$, the concentrations of chlorophylls $a$ and $b$ and their ratios (chl $a / b$ ) did not vary significantly with depth. Changes in the rate of dark respiration $(-R)$, the gross and net photosynthetic capacities $\left(P_{m,}, P_{m}^{n}\right), \alpha$, and the irradiance required for the onset of saturation $\left(I_{k}\right)$ were greater between 15 and $25 \mathrm{~m}$ than between 10 and $15 \mathrm{~m}$, despite the change in urradiance being smaller. P decreased from 119 to $34 \mu \mathrm{mol} \mathrm{O}_{2} \mathrm{~g}^{-1}$ dry wt $\mathrm{h}^{-1}$ between 10 and $25 \mathrm{~m}$. Net $24 \mathrm{~h}$ productivity $\left(P_{\mathrm{d}}^{\mathrm{n}}\right)$, given optimum atmospheric and ocean transparency, was estimated to decrease from 790 to $89 \mu \mathrm{mol} \mathrm{O}: \mathrm{g} \mathrm{g}^{-1}$ dry wt d $\mathrm{d}^{-1}$ between 10 and $25 \mathrm{~m}$ indicating a maximum photoautotrophic growth limit of $29 \mathrm{~m}$ in summer. At $10 \mathrm{~m}$ in winter, $-R_{1} I_{\mathrm{c}} I_{\mathrm{k}}$ and $\mathrm{chl} a / b$ were lower than in summer, $P_{\mathrm{m}}^{\mathrm{g}}$ and $P_{\mathrm{m}}^{\mathrm{n}}$ were similar, and the concentrations of chlorophylls $a$ and $b$ were higher, indicating adjustment of the photosynthetic apparatus to seasonal changes in light and/or temperature. Maximum $P^{n}$ was estimated to be $436 \mu \mathrm{mol} \mathrm{O} \mathrm{g}^{1}$ dry wt $\mathrm{d}^{-1}$. By adjusting the $y$-intercept of the summer bathymetric model to fit this rate, a maximum photoautotrophic growth limit of $24 \mathrm{~m}$ was indicated in winter. Although these theoretical photoautotrophic lımits reasonably correlate with the distribution of dense populations of C. taxifolia at Monaco, they are greatly inferior to its maximum reported growth depth of $99 \mathrm{~m}$. This ability to grow far deeper than the photoautotrophic limit implies significant carbon acquisition by heterotrophy.
\end{abstract}

KEY WORDS: Photosynthesis - Irradiance Adaptation - Depth - Season Caulerpa taxifolia

\section{INTRODUCTION}

Over approximately a decade, the siphonaceous green alga Caulerpa taxifolia (Vahl) C. Agardh has spread over $>30 \mathrm{~km}^{2}$ of the NW Mediterranean seabed (Meinesz et al. 1997). Its rapid expansion has been attributed to: abnormal size and growth rate (Meines. \& Hesse 1991, Meinesz et al. 1993)i strong chemical defence against herbivory and epiphytic overgrowth (Guerriero et al. 1992, 1993); efficient vegetative propagation (Meinesz \& Hesse 1991, Meinesz et al. 1993)

\footnotetext{
- Present address: Australian Institute of Marine Science, PMB No. 3, Townsville MC, Queensland 4810, Australia E-mail: j.chisholn@@aims.gov.au
}

enhanced tolerance of winter minimum seawater temperatures (Meinesz \& Hesse 1991, Meinesz \& Boudouresque 1996); an ability to colonise widely varying substrata (Meinesz et al. 1993); efficient absorption, conservation and internal recycling of nutrients (Delgado et al 1996); and peak frond length (Meinesz et al. 1993) and productivity (Gacia et al. 1996) in autumn when the biomass of native species is at a minimum. These attributes are thought to enable the alga to outcompete native macrophytes, in particular Posidonia oceanica (L.) Delile (Villèle \& Verlaque 1995) and shallow-water macroalgae (Verlaque \& Fritayre 1994). Chisholm et al. (1997) reason that growth of $C$. taxifolia may be favoured by eutrophication of substrata because the alga can take up organic $\mathrm{N}$ and inorganic 
nutrients through its subterranean rhizoids (Chisholm. et al. 1996). Rapid expansion of C. taxifolia may thus be a product of synergy between endogenous and exogenous factors

Despite this wealth of theories on the causes and effects of Caulerpa taxifolia development in the NW Mediterranean, data are still lacking on fundamental aspects of the alga's biology. The rapidity of the alga's expansion in certain environments implies very high growth rates and yet laboratory measurements have indicated only moderate rates of primary production (Gayol et al. 1995, Gacia et al. 1996). Either laboratory measurements have greatly underestimated the alga's in situ primary productivity or $C$. taxifolia derive significant organic $C$ from heterotrophy. Although Chisholm et al. (1996) have demonstrated uptake of organic $\mathrm{C}$ by $\mathrm{C}$, taxifolia, the contribution of this process to growth of the alga has not been quantified. Similarly, there have been no published reports of the in situ productivity of $C$. taxifolia, thus it has not been possible to determine the relative importance of autotrophy and heterotrophy.

This study provides the first estimates of the in situ primary productivity of Caulerpa taxifolia. Photoautotrophic metabolism is examined as a function of bathymetry and season. Data are used to estimate the autotrophic depth limits of C. taxifolia in summer and winter under optimum conditions of atmospheric and oceanic transparency. These estimates are used as a basis for discussion of nutrition, growth and expansion of C. taxifolia in the NW Mediterranean.

\section{MATERIALS AND METHODS}

Scalar irradiance, seawater temperature, and net oxygen production or consumption by samples of Caulerpa taxifolia were measured in the sea at Monaco using a purpose-built, submersible respirometer. Measurements were made at a depth of $10 \mathrm{~m}$ in December 1994 and at 10, 15 and $25 \mathrm{~m}$ in August 1995. The respirometer included a spherical quantum sensor (Li-193SA $4 \pi$. Li-Cor) and 3 cylindrical, acrylic incubation chambers (3.5 I volume), fitted with polarographic oxygen electrodes containing built-in temperature sensors (Ponselle OXY TS, Ponselle Mesure). Acrylic was used for the incubation chambers because it is non-toxic and has a refractive index similar to seawater. After construction, the chambers were soaked in a warm solution of anionic detergent $(3 \mathrm{~h})$ then immersed in freshwater ( $1 \mathrm{wk}$ ) and seawater ( $1 \mathrm{wk}$ ) to remove any toxins introduced during the fabrication process. The sensors were connected by underwater electric cables to a datalogger (Li-1000, Li-Cor) secured within a pressure-resistant, waterproof housing.

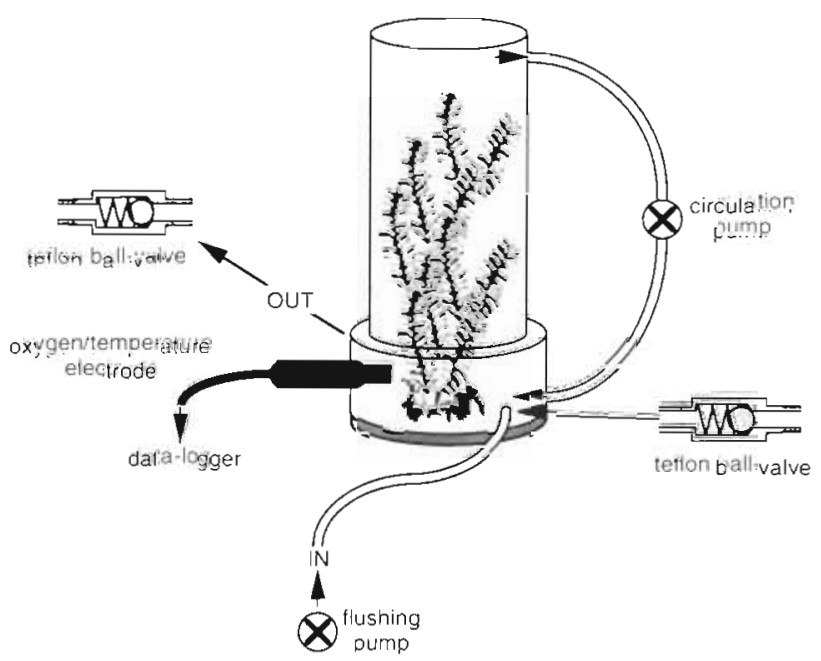

Fig. 1 One of 3 experimental incubation chambers comprising: a tall upper section $(30 \mathrm{~cm}$, clear acrylic) to enable fronds to extend vertically without restriction; a lower section (clear acrylic) containing a port for the fitted probe and water inlet and outlet ball-valves; a continuous circulation loop connecting upper and lower sections to provide water movement and mixing withun the chamber; and a base (PVC). Sections and base were connected together with stainless steel (316 grade) spring clips and sealed with rubber O-rings

The light sensor was mounted in a fixture adjacent to the sample chambers during incubations.

Sensor calibration. Oxygen sensors were calibrated every $2 \mathrm{~d}$ in $1.5 \mathrm{l}$ volumes of seawater brought to airsaturation over $24 \mathrm{~h}$ by bubbling with humidified air while stirring. Oxygen sensors were zeroed by capping the sensor heads with small polyethylene tubes containing saturated solutions of sodium sulphite. Temperature sensors were calibrated before each set of seasonal measurements against a high precision mercury thermometer. The light sensor was pre-calibrated by the manufacturer

Samples. Samples were gathered using SCUBA from locations spaced $>5 \mathrm{~m}$ apart to avoid pseudoreplication (maximum length of stolons $=2.8 \mathrm{~m}$; Meinesz et al. 1995). Samples of Caulerpa taxifolia, including the basal substrata to which their rhizoids were attached, of planar area similar to that of the incubation chambers, were carefully placed in each chamber (Fig. 1). The chambers were of sufficient height to enable the fronds to extend vertically without restriction. Samples of planar area approximately equal to that of the incubation chambers were selected to preserve natural frond densities.

Field measurements. Chambers were mixed continuously by small centrifugal pumps operating on short, external, recirculating loops connected to the upper and lower sections of each chamber (Fig. 1). Chambers were flushed with fresh seawater for $5 \mathrm{~min}$ in every 
35 min period by a timer-controlled pump. Separate electrical currents were fed to the circulation and flushing pumps through a 4-core underwater cable, connected to a shore-based power supply (240 V AC) Spring-loaded teflon ball-valves sealed the inlets and outlets of the chambers between flushings. Oxygen, temperature and irradiance were sampled every $5 \mathrm{~s}$; average readings were stored by the datalogger at 5 min intervals. Each incubation lasted a total of 24 h. Six samples of Caulerpa taxifolia were measured at each depth in 2 batches of 3 replicates. At the end of 1 set of triplicate incubations that finished close to midday, basal substrata were removed in situ from the alga's rhizoids. Measurements of the combined oxygen demand of each substratum sample plus plankton in the water column were made at a depth of $10 \mathrm{~m}$ first under high light $(1 \mathrm{~h})$ and second after covering the incubation chambers with black polythene to simulate darkness ( $1 \mathrm{~h}$ ).

Laboratory measurements. At the end of each incubation, algal tissue and substrata were transferred to plastic bags and taken immediately to the laboratory. Rhizoids were gently scraped clean of adhering substrata. The total volume of non-living material associated with samples was determined by weighing the volume of distilled $\mathrm{H}_{2} \mathrm{O}$ displaced by the material from a full spouted beaker. Algal tissues were rinsed briefly in fresh $\mathrm{H}_{2} \mathrm{O}$ to remove excess salt, blotted, placed in clean plastic bags, shielded from light, and frozen at $-20^{\circ} \mathrm{C}$. When frozen, samples were freeze-dried 48 to $72 \mathrm{~h}$ ) in the dark. Dry algal tissue was carefully separated from fine residual sand particles, weighed and homogenised. Approximately $1 \mathrm{~g}$ of the dry homogenate was removed from each sample and weighed accurately. Chlorophylls $a$ and $b$ (chl $a$ and $b$ ) were extracted sequentially from the dried subsamples into cold $90 \%$ acetone containing trace quantities of $\mathrm{MgCO}_{3}$ to prevent acidification. Two extractions were sufficient to remove $>97 \%$ of chlorophylls. Extracts were zeroed for optical density at $750 \mathrm{~nm}$ and their absorbances at $664 \mathrm{~nm}\left(\xi_{\text {,hl }}\right)$ and $647 \mathrm{~nm}$ $\left(\xi_{\text {chlb }}\right)$ were read using a spectrophotometer. Chlorophyll concentrations were calculated using the equations of Jeffrey \& Humphrey (1975) Total chl $a$ and $b$ in each sample were estimated by multiplying the quantity measured in the subsample by the ratio of total dry weight to subsample dry weight.

Flux rates. Oxygen data were adjusted for calibrations. Values obtained while the chambers were being flushed and immediately after while sensors were stabilising were eliminated from further analysis. Hourly rates of oxygen exchange were calculated by multiplying the change in $\mathrm{O}_{2}$ concentration measured over 5 min periods by $12 \times$ [chamber volume (1) - volume of the substratum (l)]. Data were normalised to dry weight (g), chl a (mg) and chl $b$ (mg).

$P$ - $I$ curves. Mean $\mathrm{O}_{2}$ flux rates were plotted against irradiance and modelled using:

(a) the hyperbolic tangent function:

$$
P=P_{\mathrm{m}}^{\mathrm{g}} \tanh \left(I / I_{\mathrm{k}}\right)+R \quad \text { (Jassby \& Platt 1976) }
$$

(b) a simple exponential function:

$$
P=P_{\mathrm{m}}^{\mathrm{g}}\left(1-\mathrm{e}^{-i / \mathrm{k}} \mathrm{k}\right)+R \quad \text { (Webb et al. 1974) }
$$

(c) a Michaelis-Menten function:

$$
P=\left[P_{\mathrm{m}}^{\mathrm{g}} I /\left(I+I_{\mathrm{k}}\right)\right]+R \quad \text { (Baly 1935) }
$$

Abbreviations used in these equations and elsewhere are defined in Table 1

The accuracy with which each model simulated the data was evaluated by non-linear, least-squares regression (JMP v3 Statistics Made Visual, SAS Institute, Inc.). The function which produced the narrowest confidence intervals around the primary parameter estimates was used to characterise the light-saturation kinetics of individual algal samples

Analyses of variance. Variation in primary $\left(-R, P_{m}^{g}\right.$ $\left.I_{k}\right)$, secondary $\left(\alpha, I_{c}, P_{\mathrm{m}}^{\mathrm{n}}, P_{\mathrm{m}}^{\mathrm{g}} /-R\right)$ and chlorophyll $(a, b$, $a / b)$ parameters as a function of depth and season was examined using 1-way analysis of variance (ANOVA; JMP v3 Statistics Made Visual). Preliminary tests for

\begin{tabular}{|c|c|}
\hline$P-1$ & Curvilinear relationship between photosynthesis and irradiance \\
\hline$-R$ & Absolute rate of dark respiration \\
\hline$P_{\mathrm{m}}^{\mathrm{g}}$ & Gross photosynthetic capacity \\
\hline$P_{\mathrm{m}}^{\mathrm{n}}$ & Net photosynthetic capacity \\
\hline$P_{\mathrm{m}}^{\mathrm{g}} /-R$ & Ratio of gross photosynthetic capacity to respiration \\
\hline$P_{d}^{q}$ & Gross photosynthesis over a day \\
\hline$P_{i}^{n}$ & Net photosynthesis over a day \\
\hline$\alpha$ & Initial slope of the P-I curve \\
\hline$I_{k}$ & $\begin{array}{l}\text { Irradiance at which the initial slope intercepts the horizontal } \\
\text { asymptote of the P-I curve }\end{array}$ \\
\hline$I_{c}$ & Irradiance at which $p^{c}=-R$ \\
\hline$I_{0}$ & Irradiance at the sea surface \\
\hline$I_{\mathrm{T}}$ & Maximum irradiance at a depth \\
\hline$z$ & Depth $(\mathrm{m})$ \\
\hline$K$ & Vertical attenuation coefficient \\
\hline$t$ & Time (min) \\
\hline d] & Length of daily photoperiod (min) \\
\hline chla & Concentration of chl a \\
\hline chl $b$ & Concentration of chl $b$ \\
\hline$c h l a / b$ & Ratio of chl $a$ to $c h l b$ \\
\hline$r^{2}$ & Coefficient of determination \\
\hline
\end{tabular}
normality (Shapiro \& Wilk 1965) and homogeneity of

Table 1. Abbreviated terms used in the text 
variance (Bartlett 1937) were carried out to ensure compliance with assumptions underlying ANOVA. Values for $I_{c}, I_{h}$, $[\mathrm{chl} a]_{\text {, }}[\mathrm{chl} b]$, and chl $a / b$ in tests for seasonal differences and $I_{\mathrm{k}}$ in a test for depth differences were transformed to render variances homogeneous using the formulas indicated in Table 2. Post-hoc, multiple, pairwise comparisons of means were made at the $5 \%$ significance level using Tukey-Kramer HSD tests (Tukey 1973. Kramer 1956, JMP v3 Statistics Made Visual) when ANOVA demonstrated significant variation in parameters as a function of bathymetry.

Regression analyses. Parameters that varied significantly with depth in ANOVA were modelled using linear regression (JMP v3 Statistics Made Visual).

Irradiance. The daily irradiance profile in the study area was cvaluatcd on the basis of measurements made on a cloud-free day in summer (25 August 1995) and a near cloud-free day in winter (6 December 1994) using. (a) a half sine function:

$$
I=I_{\mathrm{m}} \sin (\pi \tau) \quad \text { (Chalker et al. 1984) }
$$

and (b) a peaked half sine function:

$$
I=I_{\mathrm{m}}[\sin (\pi \tau)]^{n} \quad \text { (McBride 1992) }
$$

where $I_{\mathrm{m}}$ was the maximum measured irradiance; $n$ was a small number $>1,<3$; and $\tau=\left(t-t_{\text {sunnse }}\right) / d l$.

Theoretical profiles of daily irradiance under optimum conditions of atmospheric transparency (transmission coefficient $=0.67$; Ashrae 1977) and ocean clarity (Type IB Oceanic Water; Jerlov 1976) were also constructed for subsequent estimation of absolute productivity. $I_{\mathrm{m}}$ was calulated from.

$$
I_{\mathrm{m}}=I_{0} \mathrm{e}^{-K z}
$$

(Kirk 1994)

where $I_{0}$ was calculated for the latitude $43^{\circ} 45^{\prime} \mathrm{N}$ using the method of Drew (1983) and $K$ was calculated from data provided by Lüning \& Dring (1979). $d l$ was either that calculated by the method of Drew (1983) or the measured photoperiod, whichever was longer

Daily production. Daily $P_{d}^{g}$ and $P_{d}^{n}$ were calculated first using measured values for $I_{\mathrm{m}}$ by numerically integrating the mean $P$ - Imodel for each sample group with the equation that best modelled daily irradiance under cloud-free conditions (see Chalker et al. 1984). Absolute productivities were then calculated by the same procedure using maximum theoretical values for $I_{m}$ and either the measured or calculated photoperiods ( $d l$, see above). Theoretical values for $I_{\mathrm{m}}$ and $d l$ were calculated for 21 August and 7 December to correspond with the middle of each experimental period. The dark rate of respiration was assumed to persist throughout the day.

Depth limits to growth. The lower depth limit for photoautotrophic growth in summer was estimated by fitting an exponential function to a plot of $P_{\mathrm{d}}^{\mathrm{n}}$ versus depth and determining, by extrapolation, the depth at which $P_{\mathrm{d}}^{n}$ became $\leq 0$. The same parameter was estimated in winter by adjusting the $y$-intercept of the summer model to obtain the estimated value for $P_{i}$ at $10 \mathrm{~m}$ and then extrapolating the curve to find the depth at which $P_{\mathrm{d}}^{\mathrm{n}}$ became $\leq 0$.

\section{RESULTS}

Field observations. Frond densities tended to be higher at 10 and $15 \mathrm{~m}$ than at $25 \mathrm{~m}$; frond length tended to be greater at $15 \mathrm{~m}$. The substratum consisted of limestone rocks and rubble at 10 and $15 \mathrm{~m}$ and $\mathrm{a}$ mixture of fine silt and mud at $25 \mathrm{~m}$. Buried several $\mathrm{cm}$ beneath the sediment horizon at $25 \mathrm{~m}$ were the organic remains of a former seagrass bed (Ollivier 1929). Seawater temperature varied between 17 and $18^{\circ} \mathrm{C}$ during measurements in December 1994 and between 23 and $25^{\circ} \mathrm{C}$ during measurements in August 1995. 


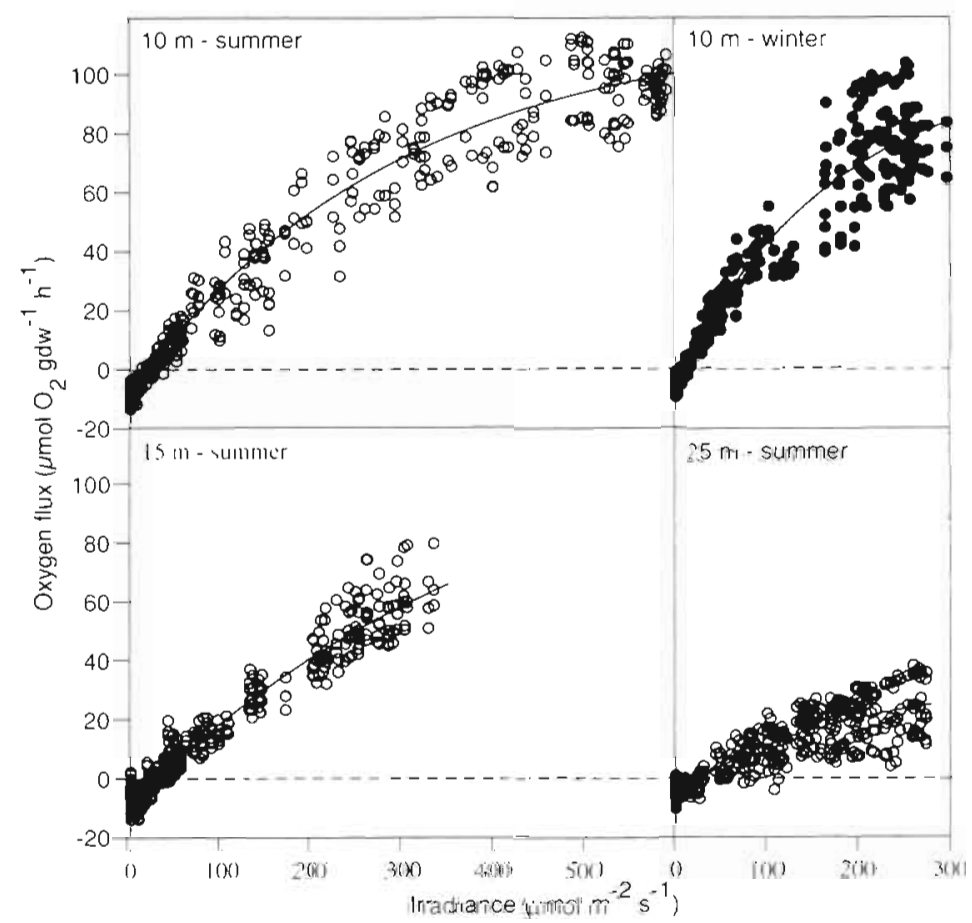

Fig. 3. Photosynthesis-irradiance relationships of Caulerpa taxifolia near Monaco, NW Mediterranean. Data are fitted by a simple exponential function (Eq. 2)

Flux rates. Comparison of net oxygen flux with irradiance under near cloudless conditions on 6 December 1994 indicated that changes in photosynthetic rate marginally lagged changes in irradiance, i.e. maximum photosynthetic rate was attained approximately 30 to $40 \mathrm{~min}$ after the solar zenith (Fig. 2). The combined oxygen demand of microscopic organisms associated with the basal substratum and water column made negligible contribution to the overall flux rate of oxygen in both the light $(0.1$ to $0.5 \%)$ and the dark $(0.8$ to $3 \%)$. No correction was applied to estimates of productivity or respiration for Caulerpa taxifolia.

$P$-I curves. On average, the simple exponential function (Eq. 2) produced the narrowest confidence intervals around the primary parameter $\left(P_{\mathrm{m}}^{\mathrm{g}}, I_{k},-R\right)$ estimates and was therefore selected for characterisation of the $P$-I response in Caulerpa taxifolia. At natural frond densities, photosynthesis did not reach light-saturation in any of the populations measured (Fig. 3). Productivity per umol irradiance decreased with depth and was slightly higher in winter (Fig. 3)
Parameters defining the mean features of the $P$-I curves, together with tissue chlorophyll concentrations and ratios, are provided in Table 2. The gross and net photosynthetic capacities of populations at $10 \mathrm{~m}$ were equal in summer and winter. Dark respiration consumed $4 \%$ of $P_{\mathrm{m}}^{\mathrm{g}}$ at $10 \mathrm{~m}$ in winter and 7 to $13 \%$ of $P_{\mathrm{m}}^{\mathrm{g}}$ between 10 and $25 \mathrm{~m}$ in summer

Variation in parameters. Except for $P_{n 1}^{\mathrm{g}}$ and $P_{m}^{n}$ parameters varied more between the 2 seasons than with depth (Table 2). $P_{m}^{\mathrm{g}}$ and $P_{\mathrm{m}}^{\mathrm{n}}$ were almost identical in summer and winter. In summer, $-R, I_{c}, I_{\mathrm{k}}$ and $c h l a / b$ increased, whereas $\alpha, P_{\mathrm{m}}^{\mathrm{g}} /-R$ and the concentrations of chl $a$ and chl $b$ decreased.

Neither $I_{c}$ nor the concentrations of chl a and chl $b$ or their ratios altered significantly as a function of bathymetry (Table 2). $-R$, $P_{\mathrm{m}}^{\mathrm{g}}, P_{\mathrm{m}}^{\mathrm{n}}, \alpha, P_{\mathrm{m}}^{\mathrm{g}} /-R$ and $I_{\mathrm{k}}$ were inversely proportionate to depth (Fig. 4, Table 3). Larger differences in parameters occurred between $15 \mathrm{~m}$ and $25 \mathrm{~m}$ than between $10 \mathrm{~m}$ and $15 \mathrm{~m}$ (Tables 2 \& 3), despite the change in irradiance being smaller (Table 4).

Irradiance. Data gathered on a cloudless day in summer (25 August 1995) at a depth of $25 \mathrm{~m}$ demonstrated that irradiance followed a peaked half sine curve (Eq. 5, $\left.\mathrm{r}^{2}=1.00\right)$ :
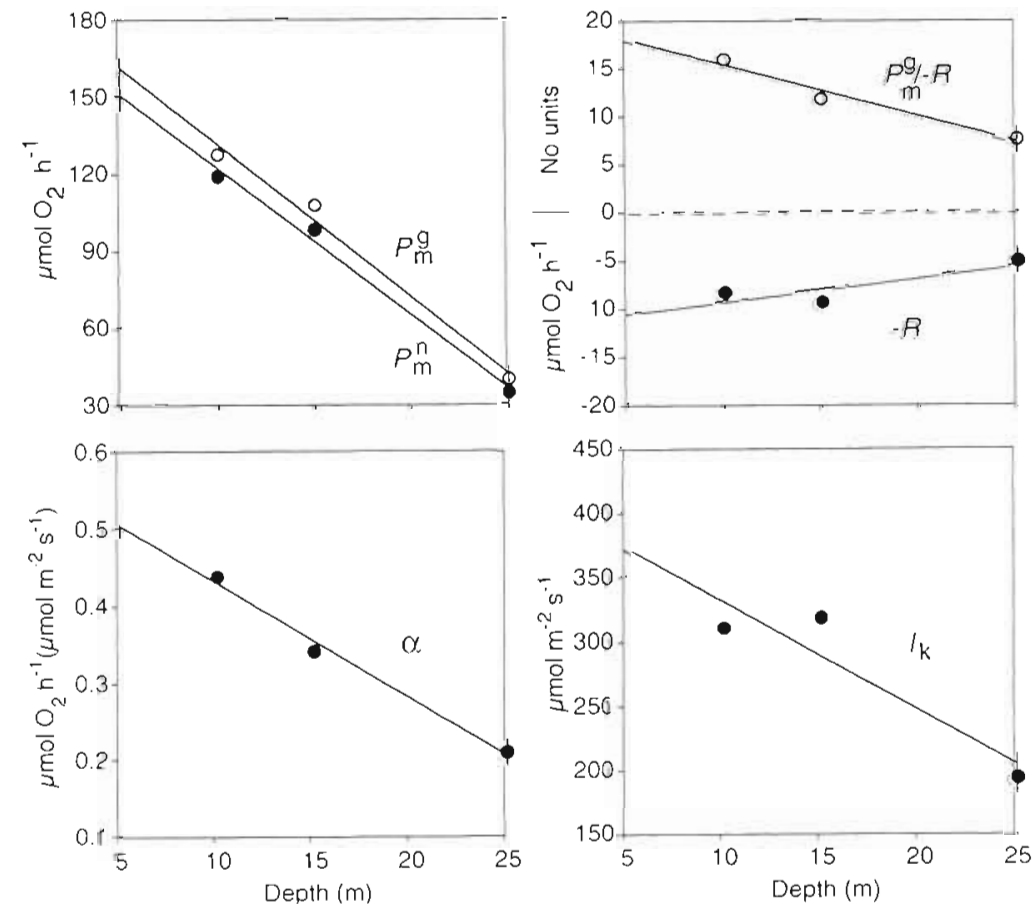

Fig. 4. P-I parameters of Caulerpa taxifolia varying linearly with depth in summer; model equations are given in Table 3 


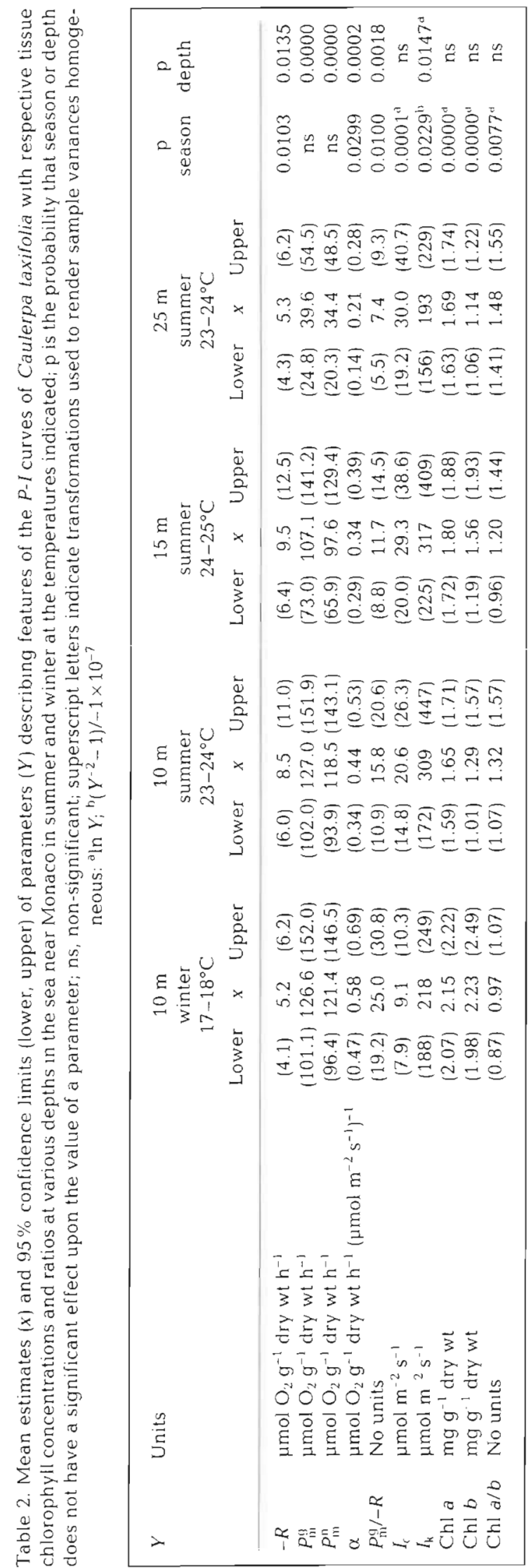

$$
I=265 \times\left[\sin \left(\pi \times\left(t-t_{\text {sunrise }}\right) / 810\right)\right]^{t .985}
$$

rather than a half sinusoid (Eq. 4, $\mathrm{r}^{2}=0.77$ ) (Fig. 5). This relationship also held in winter (Fig, 2, $r^{2}=0.99$ ), except for a small change in $n$, the power of the sine term:

$$
I=273 \times\left[\sin \left(\pi \times\left(t-t_{\text {sunise }}\right) / 555\right)\right]^{1.933}
$$

Peaked half-sinusoid irradiance profiles were thus used for calculation of daily primary production. The irradiance profiles indicated a daily photoperiod of 13 h 30 min on 25 August 1995 and 9 h 10 min on 6 December 1994; these photoperiods were, respectively, 6 min shorter and 22 min longer than those calculated using the method of Drew (1983) for 21 August and 6 December. $14.6 \%$ of $I_{0}$ penetrated to a depth of $25 \mathrm{~m}$ on 25 August 1995 indicating that the seawater was slightly more transparent than Type II Oceanic Water (Jerlov 1976). The optical transparency of the seawater during measurements in winter was between Type II and Type III Oceanic Water (Jerlov 1976).

Substitution of empirically determined irradiance maxima with values calculated for idealised conditions of atmospheric and oceanic transparency (clear sky, Type IB Oceanic Water) yielded irradiance profiles described by

$$
I=I_{\mathrm{m}} \times\left[\sin \left(\pi \times\left(t-t_{\text {sunise }}\right) / 555\right)\right]^{2032}
$$

in winter; and

$$
I=I_{\mathrm{m}} \times\left[\sin \left(\pi \times\left(t-t_{\text {sunrise }}\right) / 816\right)\right]^{2.032}
$$

in summer. Values for $I_{m}$ are given in Table $4_{i} d l$ in Eq. (9) was the empirically determined photoperiod

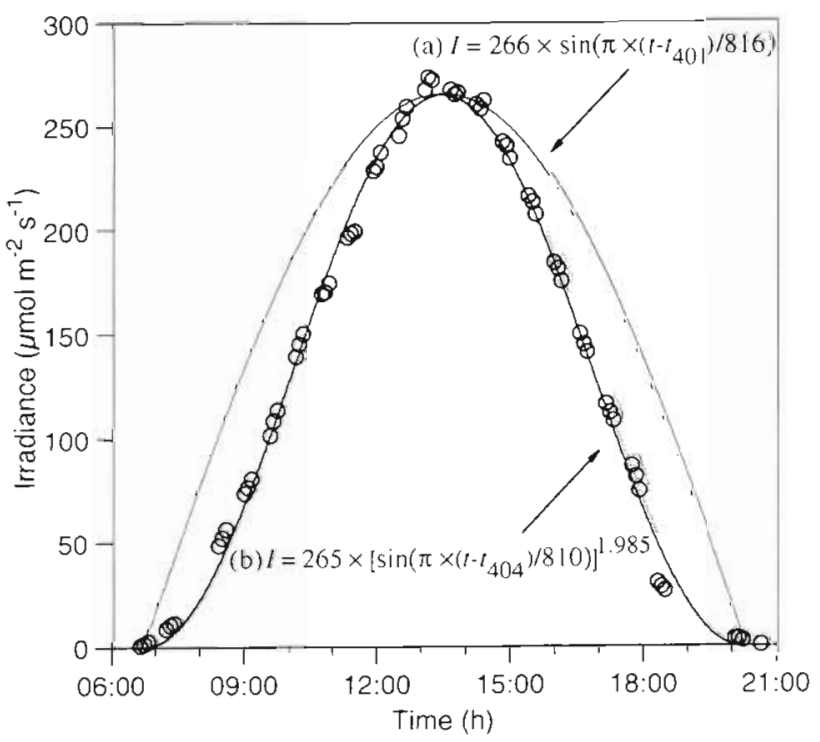

Fig. 5. Profile of the change in irradiance on 25 August 1995 at a depth of $25 \mathrm{~m}$ modelled by: (a) a half sine function $\left(\mathrm{r}^{2}=\right.$ $0.77)$; and (b) a half peaked sine function $\left(r^{2}=1.00\right)$ 
Table 3. Linear regression of parameters $(Y)$ vs depth ( $X$ in $\mathrm{m}), \mathrm{r}^{2}$ is the coefficient of determination, $\mathrm{p}$ is the probability that the slope is not significantly different from 0 . For principal variation, $>$ indicates 1 or more population means signficantly larger than another (Tukey-Kramer, $\alpha=0.05$ )

\begin{tabular}{|c|c|c|c|c|c|}
\hline$Y$ & $Y=$ & $r^{2}$ & $\mathrm{p}$ & Principal variation & Units \\
\hline$-R$ & $0.243 X-11.8$ & 0.31 & 0.0159 & $15>25 \mathrm{~m}$ & $\mu \mathrm{mol} \mathrm{O}_{2} \mathrm{~g}^{-1} \mathrm{dry} w \mathrm{th}^{-1}$ \\
\hline$P_{m}^{\mathrm{g}}$ & $190.5-5.955 X$ & 0.72 & 0.0000 & $10.15>25 \mathrm{~m}$ & $\mu \mathrm{mol} \mathrm{O}_{2} \mathrm{~g}^{-1}$ dry wt $\mathrm{h}^{-1}$ \\
\hline$P_{\mathrm{m}}^{n}$ & $178.7-5.712 X$ & 0.73 & 0.0000 & $10,15>25 \mathrm{~m}$ & $\mu \mathrm{mol} \mathrm{O} \mathrm{g}^{-1}$ dry wt $\mathrm{h}^{-1}$ \\
\hline$\alpha$ & $0.578-0.015 X$ & 0.67 & 0.0000 & $10,15>25 \mathrm{~m}$ & $\mu \mathrm{mol} \mathrm{O} 2 \mathrm{~g}^{-1}$ dry wt h $\mathrm{h}^{-1}\left(\mu \mathrm{mol} \mathrm{m}^{-2} \mathrm{~s}^{-1}\right)^{-1}$ \\
\hline$P_{\mathrm{m}}^{\mathrm{g}} /-R$ & $20.6-0.538 \mathrm{X}$ & 0.55 & 0.0004 & $10>25 \mathrm{~m}$ & No units \\
\hline$I_{c}$ & & 0.15 & ns & & $\mu \mathrm{mol} \mathrm{m} \mathrm{m}^{-2} \mathrm{~s}^{-1}$ \\
\hline$I_{k}$ & $414-8.446 X$ & 0.26 & 0.0292 & $10,15>25 \mathrm{~m}$ & $\mu \mathrm{mol} \mathrm{m} \mathrm{m}^{-2} \mathrm{~s}^{-1}$ \\
\hline $\mathrm{Chla}$ & & 0.54 & ns & & $\mathrm{mg} \mathrm{g}^{-1} \mathrm{dry} w \mathrm{t}$ \\
\hline Chl b & & 0.34 & ns & & $m g g^{-1}$ dry wt \\
\hline Chl $a / b$ & & 0.29 & ns & & No units \\
\hline
\end{tabular}

Table 4. Estimated mean $24 \mathrm{~h}$ primary productivity of Caulerpa taxifolia near Monaco under clear atmospheric conditions; theoretical values for $d l$ and $I_{m}$ calculated from Drew (1983), the latter assuming Type IB Oceanic Water (Jerlov 1976)

\begin{tabular}{|c|c|c|c|c|c|c|c|c|c|}
\hline \multirow[t]{2}{*}{ Parameter } & \multirow[t]{2}{*}{ Units } & \multicolumn{2}{|c|}{$10 \mathrm{~m}$ winter } & \multicolumn{2}{|c|}{$10 \mathrm{~m}$ summer } & \multicolumn{2}{|c|}{$15 \mathrm{~m}$ summer } & \multicolumn{2}{|c|}{$25 \mathrm{~m}$ summer } \\
\hline & & Actual & Theory & Actual & Theory & Actual & Theory & Actual & Theory \\
\hline dl & $\min$ & 555 & 533 & 810 & 816 & 810 & 816 & 810 & 816 \\
\hline$I_{i i}$ & Hmol m $\mathrm{m}^{-2} \mathrm{~s}^{-1}$ & 296 & 417 & 589 & 983 & 333 & 723 & 265 & 391 \\
\hline$p_{\mathrm{d}}^{9}$ & $\mu \mathrm{mol} \mathrm{O} \mathrm{O}_{2} \mathrm{~g}^{-1}$ dry wt d $\mathrm{d}^{-1}$ & 439 & 560 & 782 & 994 & 404 & 694 & 162 & 216 \\
\hline$P_{\mathrm{d}}^{\mathrm{n}}$ & $\mu \mathrm{mol} \mathrm{O}_{2} \mathrm{~g}^{-1}$ dry wt d $\mathrm{d}^{-1}$ & 314 & 436 & 578 & 790 & 176 & 466 & 35 & 89 \\
\hline
\end{tabular}

because this was longer than the interval from sunrise to sunset (see Chalker et al. 1984)

Daily production. Whole day net productivity $\left(P_{\mathrm{d}}^{\mathrm{n}}\right)$, using measured dimensions for $I_{\mathrm{m}}$ and $d l$, was esti-

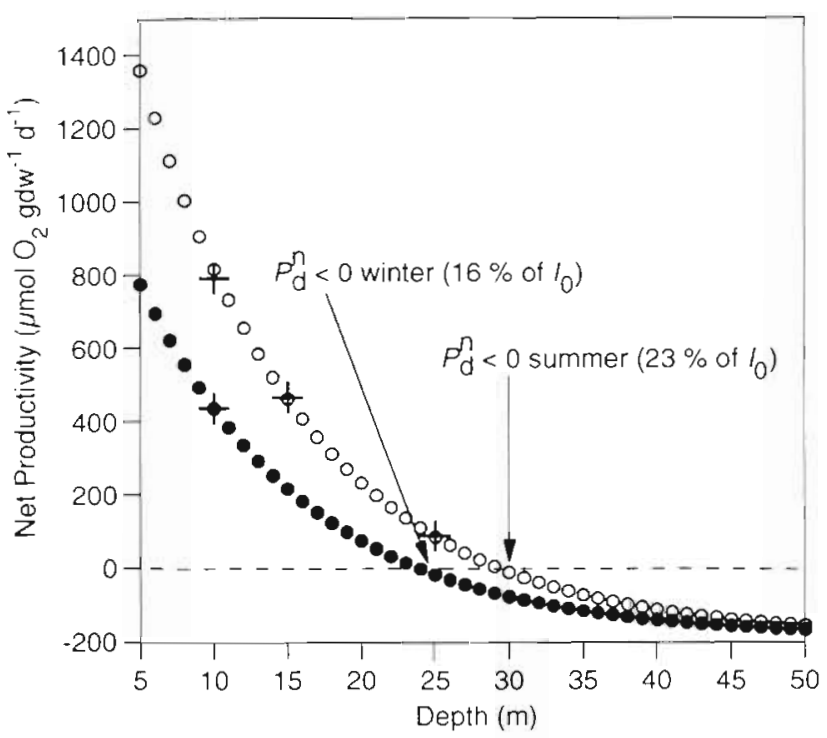

Fig. 6. Declining exponential models of $P^{n}$ vs depth for Caulerpa taxifolia in summer $(0)$ and winter $(-)_{\mathrm{d}}=2386 \mathrm{e}^{(-0.087173)}-184$ for summer and $P_{\mathrm{d}}^{\mathrm{n}}=1482 \mathrm{e}^{(-0.087172)}-184$ for winter; $(+)$ estimated productivities by measurement. Winter model was constructed by altering the $y$-intercept of the summer model to fit winter data mated to range from $578 \mu \mathrm{mol} \mathrm{O} \mathrm{O}_{2} \mathrm{~g}^{-1}$ dry wt at $10 \mathrm{~m}$ to $35 \mu \mathrm{mol} \mathrm{O} \mathrm{O}^{-1}$ dry wt at $25 \mathrm{~m}$ in summer; $P_{\mathrm{d}}^{\mathrm{n}}$ in winter was estimated to be $54 \%$ of that calculated for $10 \mathrm{~m}$ populations in summer (Table 4). Respiration consumed an increasing proportion of $P_{d}^{g}$ as depth increased in summer ( 26 to $78 \%$ between 10 and $25 \mathrm{~m}$ ) and $28 \%$ of $P_{\mathrm{d}}^{\mathrm{g}}$ at $10 \mathrm{~m}$ in winter.

Maximum theoretical $P_{d}^{n}$, assuming zero cloud cover and light attenuation by Type IB Oceanic Water, was estimated to range from 790 to $89 \mu \mathrm{mol} \mathrm{O} \mathrm{O}^{-1}$ dry wt between 10 and $25 \mathrm{~m}$ in summer and to be $436 \mu \mathrm{mol}$ $\mathrm{O}_{2} \mathrm{~g}^{-1}$ dry wt at $10 \mathrm{~m}$ in winter (Table 4).

Depth limits to growth. Exponential models of the change in maximum theoretical $P_{d}^{n}$ with depth indicated that there was insufficient primary production to meet respiratory demand at depths greater than $29 \mathrm{~m}$ in summer and $24 \mathrm{~m}$ in winter (Fig, 6).

\section{DISCUSSION}

Drew \& Abel (1990) had difficulty determining the light-saturation characteristics of Halimeda because the position of the chloroplasts within segments changed as a function of irradiance and photoperiod. Movement of chloroplasts has been observed in other siphonaceous algae, including Bryopsis (Steinecke 1925), Caulerpa prolifera (Dawes \& Barilotti 1969), C. 
racemosa (Horstmann 1983) and in C. taxifolia by ourselves. Although chloroplast redistribution in $C$. taxifolia does not occur to the extent observed in Halimeda (Drew \& Abel 1990), it may account for some of the variability in light-saturation data and for apparent lags between changes in irradiance and changes in photosynthetic rate (Fig. 2). However, providing sufficient measurements are made over the course of the day, it is possible to model the P-I responses of different populations with reasonable accuracy (Fig. 3).

The most surprising feature of the data is that Caulerpa taxifolia showed almost none of the documented adaptative responses of marine plants to bathymetric changes in irradiance. Such photoadaptations include: more efficient use of low light (i.e. higher $\alpha_{;}$King \& Shramm 1976; Ramus et al. 1976, Peckol \& Ramus 1988); lower irradiance requirements for respiratory compensation (Steemann. Nielsen 1975, King \& Shramm 1976, Harris 1978, Kremer 1981, Lüning 1990); increased concentrations of chl $a$ in tissues and increased synthesis of photosynthetic accessory pigments (Ramus et al. 1976, Li \& Titlyanov 1981, Ramus 1981, Dring 1990). The only significant response to decreased irradiance was a reduction in $I_{k}$ (the amount of irradiance needed to saturate the light reactions of photosynthesis) and this only took place between 15 and $25 \mathrm{~m}$. In consequence, the gross photosynthetic capacity of $C$. taxifolia decreased by $69 \%$ between 10 and $25 \mathrm{~m}$, while respiration decreased by only $38 \%$ (Table 2). This ratio in fact overestimated the ability of photosynthesis to satisfy respiratory demand because populations never reached photosynthetic capacity (Fig. 3).

This rapid decline in $P_{\mathrm{m}}^{\mathrm{g}} /-R$ severely constrained the estimated lower depth limit of net $24 \mathrm{~h}$ autotrophic production. Even under the most favourable conditions of atmospheric and ocean transparency, the rate of photosynthesis was estimated to be insufficient to sustain respiratory demand at depths $>29 \mathrm{~m}$ in summer and $>24 \mathrm{~m}$ in winter (Fig 5) Although these theoretical depth limits correspond fairly well with the distribution of dense populations of Caulerpa taxifolia near Monaco, they are far short of the maximum reported depth of occurrence of $99 \mathrm{~m}$ (Belsher \& Meinesz 1995).

Chisholm et al. (1996) have shown that Caulerpa taxifolia has the ability to take up organic $\mathrm{C}$ and $\mathrm{N}$ and inorganic $\mathrm{P}$ directly from substrata, but the degree to which this process contributes to growth of C. taxifolia has not been quantified. Chisholm et al. (1997) have suggested that rapid expansion of C. taxifolia may be linked to urban waste-water discharge and/or high concentrations of organic compounds in the substratum. Assuming that normal environmental conditions prevailed during the study, data indicate that $C$. taxi- folia must derive significant organic resources from heterotrophy.

Changes in P-I parameters and chlorophyll concentrations were observed between winter and summer. However, the lack of photoadaptive response to bathymetric changes in irradiance suggests that these seasonal changes were largely caused by differences in seawater temperature (see Gayol et al. 1995).

Compared with in situ data reported here, laboratory measurements have provided lower estimates of $I_{k}$, lower estimates of $I_{c}$ at summer seawater temperatures, higher estimates of $\alpha$, similar or higher estimates of $P_{\mathrm{m}}^{\mathrm{g}}$ and $P_{\mathrm{m}}^{\mathrm{n}}$ and more variable estimates of $-R$ (Gayol et al. 1995, Gacia et al. 1996; Table 5). Much of this variation may have been due to differences in selfshading: Gacia et al. (1996) used excised fronds; Gayol et al. (1995) used small unattached samples; however this study used attached samples with high natural frond densities. Comparison of the parameter dimensions reported by these 3 studies indicates a degree of correlation between the tissue biomass and the estimated values of $\alpha_{1} I_{c}$ and $I_{k}$ (Table 5). Highest overall efficiencies and rates of photosynthesis were determined on excised fronds (Gacia et al. 1996), suggesting that stolon and rhizoid tissues contribute less to productivity. Lowest efficiencies and rates of photosynthesis were determined for the high biomass samples measured in this study. Photoautotrophic growth of Caulerpa taxifolia in the field may thus be self-limited by tissue biomass. By corollary, if populations are significantly more efficient in their use of irradiance at low tissue biomass and biomass decreases with depth, then the true limits of photoautotrophic survival may be greater than predicted by this study.

Except for data obtained by Gacia et al. (1996) in November 1993, all measured $P_{\mathrm{m}}^{\mathrm{n}}$ for Caulerpa taxifolia fall within the range of values reported for other Caulerpa species: 20 to $207 \mu$ mol $\mathrm{O}_{2} \mathrm{~g}^{-1}$ dry wt $\mathrm{h}^{-1}$ (O'Neal \& Prince 1982, 1988, Gattuso \& Jaubert 1985 Gattuso 1989, Terrados \& Ros 1991, 1992). Gacia et al. (1996) argued that maximum photosynthetic capacity in November when the biomass and productivity of native marine plants are most reduced may provide C. taxifolia with a competitive advantage. Data provided here indicate photosynthetic capacity has less effect on overall productivity than solar angle and length of daily photoperiod (cf. Tables 3 \& 4).

Using a photosynthetic quotient $(P Q)$ of 1 , biomass data of Verlaque \& Fritayre (1994) and an assumption that maximum photosynthesis occurred for $6 \mathrm{~h} \mathrm{~d}^{-1}$ in winter and $10 \mathrm{~h} \mathrm{~d}^{-1}$ in summer, Gacia et al. (1996) estimated that Caulerpa taxifolia could fix 1.95 to $8.57 \mathrm{~g} \mathrm{C} \mathrm{m}^{-2} \mathrm{~d}^{-1}$ at a depth of $9 \mathrm{~m}$. However, we believe that Gacia et al. (1996) may have misconstrued the biomass data of Verlaque \& Fritayre (1994) in so far as 
Table 5. Available light-saturation data for Caulerpa taxifolia at similar seawater temperatures or times of year. Column headers indicate: data source; laboratory or field data; algal tissues sampled; if rhizoids were still attached to a substratum; site of sample collection or measurement; year; month or season; and seawater temperature during measurement

\begin{tabular}{|c|c|c|c|c|c|c|c|c|c|}
\hline \multirow[t]{2}{*}{ Y } & \multicolumn{3}{|c|}{$\begin{array}{c}\text { Gayol et al. (1995) } \\
\text { Laboratory } \\
4 \text { fronds + stolon +rhizoids } \\
\text { No substratum } \\
\text { Monaco } \\
\text { From } 10 \mathrm{~m} \text {, cultured } \\
1993 \\
\text { Winter }\end{array}$} & \multicolumn{3}{|c|}{$\begin{array}{c}\text { Gacia et al. (1996) } \\
\text { Laboratory } \\
1-2 \text { excised fronds } \\
\text { No substratum } \\
\text { Cap Martin, France } \\
\text { From } 9 \mathrm{~m} \\
1993-94\end{array}$} & \multirow{2}{*}{\multicolumn{2}{|c|}{$\begin{array}{c}\text { This study } \\
\text { Field } \\
\text { Fronds + stolons + rhizoid } \\
\text { Substratum } \\
\text { Monaco } \\
\text { At } 10 \mathrm{~m} \\
1994-95 \\
\text { Dec Aug } \\
17-18^{\circ} \mathrm{C} \quad 23-24^{\circ} \mathrm{C}\end{array}$}} & \multirow[t]{2}{*}{ Units of $Y$} \\
\hline & $14^{\circ} \mathrm{C}$ & $18^{\circ} \mathrm{C}$ & $25^{\circ} \mathrm{C}$ & $13^{\circ} \mathrm{C}$ & $17^{\circ} \mathrm{C}$ & $23^{\circ} \mathrm{C}$ & & & \\
\hline$-R$ & 6.9 & 10 & 15.5 & 12.4 & 6.6 & 23.5 & 5.2 & 8.5 & $\mu \mathrm{mol} \mathrm{O} \mathrm{O}_{2} \mathrm{~g}^{-1} \mathrm{dry} w \mathrm{wt} \mathrm{h}^{-1}$ \\
\hline$P_{\mathrm{m}}^{\mathrm{g}}$ & 97 & 130 & 208 & $115^{\mathrm{a}}$ & $326^{\mathrm{a}}$ & $222^{a}$ & 127 & 127 & $\mu \mathrm{mol} \mathrm{O}_{2} \mathrm{~g}^{-1}$ dry wt h $\mathrm{h}^{-1}$ \\
\hline$P_{\mathrm{m}}^{\mathrm{n}}$ & 90 & 120 & 193 & $102^{\mathrm{a}}$ & $318^{\mathrm{a}}$ & $199^{\mathrm{a}}$ & 121 & 119 & $\mu \mathrm{mol} \mathrm{O}_{2} \mathrm{~g}^{-1}$ dry wt $\mathrm{h}^{-1}$ \\
\hline$\alpha$ & 0.79 & 0.81 & 1.07 & 1.15 & 2.16 & 1.34 & 0.58 & 0.44 & $\mu \mathrm{mol} \mathrm{O}_{2} \mathrm{~g}^{-1}$ dry wt h $\mathrm{h}^{-1}\left(\mu \mathrm{mol} \mathrm{m}^{-2} \mathrm{~s}^{-1}\right)^{-1}$ \\
\hline$P_{\mathrm{m}}^{\mathrm{g}} /-R$ & 14 & 13.6 & 13.5 & 9.3 & 49.4 & 9.45 & 25.0 & 15.8 & No units \\
\hline$I_{c}$ & 9 & 12 & 15 & 8 & 2 & 8 & 9 & 21 & $\mu \mathrm{mol} \mathrm{m}^{-2} \mathrm{~s}^{-1}$ \\
\hline$I_{\mathrm{k}}$ & 122 & 161 & 195 & 100 & 151 & 166 & 218 & 310 & hmol m $\mathrm{m}^{-2} \mathrm{~s}^{-1}$ \\
\hline
\end{tabular}

they presented essentially the same data ${ }^{1}$ for organic dry weight ('ODW') as Verlaque \& Fritayre (1994) provided for total dry weight. Unless we have misinterpreted Gacia et al. (1996), they calculated organic dry weight by subtracting a mean annual ash content of $43.1 \%$ from total dry weight. If this is correct, their estimates should be reduced by the same proportion, yielding a range of 1.11 to $4.88 \mathrm{~g} \mathrm{C} \mathrm{m}^{-2} \mathrm{~d}^{-1}$. Using their chosen value of 1 for $P Q$ and the biomass data of Verlaque \& Fritayre (1994), we obtained very similar estimates of $P_{\mathrm{d}}^{\mathrm{n}}$ at $10 \mathrm{~m}: 1.81 \mathrm{~g} \mathrm{C} \mathrm{m}^{-2} \mathrm{~d}^{-1}$ in December and $4.24 \mathrm{~g} \mathrm{C} \mathrm{m}^{-2} \mathrm{~d}^{-1}$ in August. A value of 1 for $P Q$ is probably too low for most marine algae (Ryther 1956, Strickland 1960, Littler \& Murray 1974, Buesa 1980); using a more realistic value of 1.21 (Buesa 1980) decreased estimates of net organic carbon productivity to $1.5 \mathrm{~g} \mathrm{C} \mathrm{m}^{-2} \mathrm{~d}^{-1}$ in winter and $4 \mathrm{~g} \mathrm{C} \mathrm{m}^{-2} \mathrm{~d}^{-1}$ in summer.

Multiplying these rates of carbon production by Gacia et al.'s (1996) ratio of dry wt:ODW (1.757) indicates biomass productivities at a depth of $10 \mathrm{~m}$ of $2.6 \mathrm{~g}$ dry wt $\mathrm{m}^{-2} \mathrm{~d}^{-1}$ in winter and $7 \mathrm{~g}$ dry $\mathrm{wt} \mathrm{m}^{-2} \mathrm{~d}^{-1}$ in summer. Crudely assuming that winter and summer rates each apply for half of the year and that the ratio of winter to summer production does not alter with bathymetry indicates annual biomass production rates of $1760 \mathrm{~g}$ dry wt $\mathrm{m}^{-2} \mathrm{yr}^{-1}$ at $10 \mathrm{~m}, 1100 \mathrm{~g}$ dry wt m $\mathrm{m}^{-2} \mathrm{yr}^{-1}$ at $15 \mathrm{~m}$ and $210 \mathrm{~g}$ dry wt m $\mathrm{m}^{-2} \mathrm{yr}^{-1}$ at $25 \mathrm{~m}$. Measurements made by Verlaque \& Fritayre (1994) indicated an annual

'But Verlaque \& Fritayre (1994) reported biomasses of $345 \mathrm{~g}$ dry wt $\mathrm{m}^{-2}$ in winter and $448 \mathrm{~g}$ dry $w \mathrm{~m}^{-2}$ in summer, not $332 \mathrm{~g}$ dry wt $\mathrm{m}^{-2}$ in winter and $447 \mathrm{~g}$ dry $\mathrm{wt} \mathrm{m}^{-2}$ in summer as stated by Gacia et al. (1996) mean biomass of $411 \mathrm{~g}$ dry wt $\mathrm{m}^{-2}$ at $10 \mathrm{~m}$ at Cap Martín, France, $5 \mathrm{~km}$ east of Monaco, in 1992. Between November 1996 and April 1997, we estimated mean biomasses of $221 \mathrm{~g}$ dry wt $\mathrm{m}^{-2}$ at $15 \mathrm{~m}$ and $160 \mathrm{~g}$ dry wt $\mathrm{m}^{-2}$ at $25 \mathrm{~m}$ in the study area at Monaco (calculated using a ratio of 1:10 dry weight to wet weight). Providing there is no loss of tissue, these estimates very roughly suggest that Caulerpa taxifolia could increase its surface cover annually by a factor of 4 at 10 and $15 \mathrm{~m}$ but only by a factor of 1.3 at $25 \mathrm{~m}$ assuming maintenance of uniform biomass. Meinesz et al. (1997) document an expansion factor of about 10 until population growth becomes limited, presumably by substratum availability. They also provide data which indicate that the depth interval most widely colonised by the alga in the Monaco region is 20 to $50 \mathrm{~m}$ (their Table I). Although these data do not consider differences in biomass between one area and another, nor the possibility of higher photosynthetic rates at the leading edges of populations due to lower tissue biomass (see earlier discussion), or of the possibility of periodic nutrient events, they strongly suggest that rapid growth of the alga in parts of the NW Mediterranean cannot be explained solely on the basis of autotrophy.

The species' success may be due to an ability to acquire nutrients from substrata and to derive nutrition from both autotrophy and heterotrophy (Chisholm et al. 1996, 1997). Evidence of heterotrophy among eukaryotes continues to accumulate. Many microalgae are able to assimilate organic C and N (Droop 1974, Neilson \& Lewin 1974, Wheeler et al. 1974, 1977, Lu \& Stephens 1984, Soeder \& Hegewald 1988, Flynn 1990, Combres et al. 1994, Ietswaart et al. 1994, Lewitus \& Kana 1994). 
Terrestrial plants, growing in nutrient-poor or organically rich soils, satisfy much of their $\mathrm{N}$ requirement by uptake of dissolved organic compounds (Chaplin et al. 1993, Kielland 1994, Northrup et al. 1995). While heterotrophy has not been studied extensively in macroalgae, certain species are able to assimilate organic $\mathrm{C}$ and/or $N$ directly (see Kremer 1981) or by association with symbiotic fungi (Kingham \& Evans 1986). Although Kremer (1981) considers it unlikely that uptake of organic C plays a significant role in the carbon balance of seaweeds, the supplementation of photoautotrophic metabolism with heterotrophy might explain certain anomalies reported in the literature. Assimilation of organic compounds could, for example, account for the paradoxical growth of Laminaria ochroleuca at a depth of $50 \mathrm{~m}$ in the Straits of Messina (Drew et al. 1982), decoupling of photosynthetic rate and stolon elongation in Caulerpa paspaloides during winter (O'Neal \& Prince 1988), and why newly collected samples of C. racemosa var. uvifera consumed organic carbon faster than they produced it (Riechert \& Dawes 1986).

Acknowledgoments. We thank Y Berard, J.-P. Gattuso, P. Gayol, J. Kiernicka, M. Marchıretti, F. Priouzo and S. Romaine for technical assistance, C. Falconetti and S. Reynaud for help in the field, the Staff of the Musée Océanographique de Monaco for logistical support and 3 anonymous reviewers for helpful comments on the manuscript. Funds were provided by the Principality of Monaco, the Council of Europe and Showboat International.

\section{LITERATURE CITED}

ASHRAE (1977) Handbook of fundamentals. Am Soc Heat Refrng Airconditioning Eng, New York, p 475-476

Baly ECC (1935) The kinetics of photosynthesis. Proc R Soc Lond Ser B Biol Sci 117:218-239

Bartlett MS (1937) Some examples of statistical methods of research in agriculture and applied biology. J Royal Statıst Soc Suppl 4:137-170

Belsher T. Meinesz A (1995) Deep water dispersal of the tropical alga Caulerpa taxifolla introduced into the Mediterranean. Aquat Bot 51:163-169

Buesa RJ (1980) Photosynthetic quotient of marine plants Photosynthetica 14:337-342

Chalker BE, Cox T, Dunlap WC (1984) Seasonal changes in primary production and photoadaptation by the reef-building coral Acropora granulosa on the Great Barrier Reef. In: Holm-Hansen O, Bolis L, Gilles R (eds) Lecture notes on coastal and estuarine studies, Vol 8. Marine phytoplankton and productivity. Springer-Verlag, Berlin, p 73-88

Chaplin FS III, Moilanen L, Kielland K (1993) Preferential use of organic nitrogen for growth by a non-mycorrhizal arctic sedge. Nature 361:150-153

Chisholm JRM, Dauga C, Ageron E, Grimont PAD, Jaubert JM (1996) 'Roots' in mixotrophic algae. Nature 381:382

Chisholm JRM, Fernex FE, Mathieu D, Jaubert JM (1997) Waste-water discharge, seagrass decline and algal proliferation on the Cote d'Azur. Mar Pollut Bull 34:78-84

Combres C. Laliberté G, Sevrin Reyssac J, de la Noüe J (1994) Effect of acetate on growth and ammonium uptake in the microalga Scenedesmus obliquus. Physiol Plant 91:729-734
Dawes CJ, Barilloti DC (1969) Cytoplasmic organization and rhythmic streaming in growing blades of Caulerpa prolifera. Am J Bot 56:8-15

Delgado O, Rodriguez-Prieto C, Gacia E, Ballesteros E (1996) Lack of severe nutrient limitation in Caulerpa taxifolia (Vahil C. Agardh, an introduced seaweed spreading over the oligotrophic northwestern Mediterranean. Bot Mar 39: 61-67

Drew EA (1983) Physiology of Laminaria. II. Seasonal variation of photosynthesis and respiration in Laminaria digitata Lamour. Laminaria hyperborea (Gunn.) Fosl. and Laminaria saccharina (L.) Lamour. and a model for calculation of annual carbon budgets. PSZN I: Mar Ecol 4:227-250

Drew EA, Abel KM (1990) Studies on Halimeda. III. A daily cycle of chloroplast migration within segments. Bot Mar 33:31-45

Drew EA, Ireland JF, Muir C, Robertson WAA, Robinson JD (1982) Photosynthesis, respiration and other factors influencing the growth of Laminaria ochroleuca Pyl. below $50 \mathrm{~m}$ in the Straits of Messina. PSZN I: Mar Ecol 3: 335-355

Dring MJ (1990) Light harvesting and pigment composition in marine phytoplankton and macroalgae. In: Herring PJ, Campbell AK, Whitfield M, Maddock L (eds) Light and life in the sea. Cambridge University Press, Cambridge, p $89-103$

Droop MR (1974) Heterotrophy of carbon. In: Stewart WDP (ed) Alyal physiology and biochemistry. University of California Press, Los Angeles, p 530-559

Flynn KJ (1990) Composition of intracellular and extracellular pools of amino acids, and amino acid utilization of microalgae of different sizes. J Exp Mar Biol Ecol 139:151-166

Gacia E, Rodriguez-Preto C, Delgado O, Ballesteros E (1996) Seasonal light and temperature responses of Caulerpa taxifolla from the northwestern Mediterranean. Aquat Bot $53: 215-225$

Gattuso JP (1989) Effect of temperature on the photosynthesis-irradiance curves of two Caulerpales algae grown in aquaria. Bull de l'Institut océanographique, Monaco, no. spécial 5:173-180

Gattuso JP, Jaubert J (1985) Photosynthesis and respiration of Caulerpa racemosa (Chlorophyceae, Caulerpales) grown in aquaria: effects of light and temperature. Bot Mar 28: $327-332$

Gayol P, Falconetti C, Chisholm JRM, Jaubert JM (1995) Metabolic responses of low-temperature-acclimated Caulerpa taxifolia (Chlorophyta) to rapidly elevated temperature. Bot Mar 38:61-67

Guerriero A, Marchetti F, D'Ambrosio, Senesi S, Dini F, Pietra F (1993) New ecotoxicologically and biogenetically relevant terpenes of the tropical green seaweed Caulerpa taxifolia which is invading the Mediterranean. Helv Chim Acta $76: 855-864$

Guerriero A, Meinesz A, D'Ambrosio M. Pietra F (1992) Isolation of toxic and potentially toxic sesqui- and monoterpenes from the tropical green seawced Caulerpa taxifolia which has invaded the region of Cap Martin and Monaco. Helv Chim Acta 75:689-695

Harris GP (1978) Photosynthesis, productivity and growth. Ergeb Limnol 10:1-171

Horstmann U (1983) Cultivation of the green alga Caulerpa racemosa, in tropical waters and some aspects of its physiological ecology. Aquaculture 32:361-3;1

letswaart T, Schneider PJ, Prins RA (1994) 1.tilization of organic nitrogen sources by two phytoplankton species and a bacterial isolate in pure and mixed cultures. Appl Environ Microbiol 60:1554-1560 
Jassby AD, Platt T (1976) Mathematical formulation of the relationship between photosynthesis and light for phytoplankton. Limnol Oceanogr 21:540-547

Jeffrey SW, Humphrey GF (1975) New spectrophotometric equations for determining chlorophylls $a, b, c_{1}$, and $c_{2}$ in higher plants, algae and natural phytoplankton. Biochem Physiol Pflanz 167:191-194

Jerlov NG (1976) Marine optics. Elsevier, Amsterdam

Kielland K (1994) Amino acid absorption by arctic plants: implications. Ecology 75:2373-2383

King RJ, Shramm W (1976) Photosynthetic rates of marine algae in relation to light intensity and seasonal variation. Mar Biol 37:215-222

Kingham DC, Evans LV (1986) The Pelvetia/Mycosphaerella interrelationship. In: Moss ST (ed) The biology of marine fungi. Cambridge University Press, Cambridge, p $177-187$

Kirk JTO (1994) Light and photosynthesis in aquatic ecosystems. Cambridge University Press, Cambridge

Kramer CY (1956) Extension of multiple range tests to group means with unequal numbers of replications. Biometrics 12:309-310

Kremer BP (1981) Carbon metabolism. In: Lobban CS, Wynne MJ (eds) The biology of seaweeds. Blackwell Scientific Oxford, p 493-533

Lewitus AJ, Kana TM (1994) Responses of estuarine phytoplankton to exogenous glucose: stimulation versus inhibition of photosynthesis and respiration. Limnol Oceanogr 39:182-189

Li BD, Titlyanov EA (1981) Adaptation of benthic plants to light. 3. Content of photosynthetic pigments in marine macrophytes from differently illuminated habitats. Sov J Mar Biol 4:597-604

Littler MM, Murray SN (1974) The primary productivity of marine macrophytes from a rocky shore intertidal community. Mar Biol 27:131-135

Lu M. Stephens GC (1984) Demonstration of net flux of free amino acids in Phaeodactylum tricornutum using high performance liquid chromatography. J Phycol 20: $584-589$

Lüning K (1990) Seaweeds: their environment, biogeography, and ecophysiology. John Wiley and Sons, Inc, New York

Lüning K, Dring MJ (1979) Continuous underwater light measurement near Helgoland (North Sea) and its significance for characteristic light limits in the sublittoral region. Helgol Meeresunters 32:403-424

McBride GB (1992) Simple calculation of daily photosynthesis by means of five photosynthesis-light equations. Limnol Oceanogr 37:1796-1808

Meinesz A, Benchou L, Blachier J, Komatsu T, Lemée R, Molenaar H, Mari X (1995) Variations in the structure, morphology and biomass of Caulerpa taxifolia in the Mediterranean Sea. Bot Mar 38:499-508

Meinesz A, Boudouresque CF (1996) Sur l'origine de Caulerpa taxifolia en Méditerranée. C R Acad Sci Paris, Vie 319:603-613

Meinesz A, Cottalorda JM, Chiaverini D, Braun M, Carvalho $N$, Febvre M, Ierardi S, Mangialajo L, Passeron-Seitre G, Thibaut T, Vaugelas de J (1997) Suivi de l'invasion de l'alque tropicale Caulerpa taxifolia devant les côtes françaises de la Méditerranée, situation au 31-12-1996. Ed Laboratoire Environnement Marin Littoral, Université de Nice-Sophia Antipolis et GIS Posidonie, GIS Posidonie Publ, Marseille

Meinesz A, de Vaugelas J, Hesse B, Mari X (1993) Spread of the introduced tropical green alga Caulerpa taxifolia in northern Mediterranean waters. J Appl Phycol 5:141-147
Meinesz A, Hesse B (1991) Introduction et invasion de l'algue tropicale Caulerpa taxifolia en Méditerranée nord-occidentale. Oceanol Acta 14:415-426

Nielsen AH, Lewin RA (1974) The uptake and utilization of organic carbon by algae: an essay in comparative biochemistry. Phycologia 13:227-264

Northrup RR, Yu Z, Dahlgren RA, Vogt KA (1995) Polyphenol control of nitrogen release from pine litter Nature 377 : $227-229$

Ollivier G (1929) Etude de la flore marine de la Côte d'Azur. Ann lnst Océanogr Paris 8, No. 3

O'Neal SW, Prince JS (1982) Relationship between seasonal growth, photosynthetic production and apex mortality of Caulerpa paspaloides (Chlorophyceae). Mar Biol 72:61-67

$\mathrm{O}^{\prime}$ Neal SW, Prince JS (1988) Seasonal effects of light, temperature, nutrient concentration and salinity on the physiology and growth of Caulerpa paspaloides (Chlorophyceae). Mar Biol 97:17-24

Peckol P, Ramus J (1988) Abundances and physiological properties of deep-water seaweeds from Carolina outer continental shelf. J Exp Mar Biol Ecol 115:25-39

Ramus J (1981) The capture and transduction of light energy. In: Lobban CS, Wynne MJ (eds) The biology of seaweeds. Blackwell Scientific, Oxford, p 458-492

Ramus J, Beale SI, Mauzerall D, Howard KL (1976) Changes in photosynthetic pigment concentration of seaweeds as a function of water depth. Mar Biol 37:223-229

Riechert R, Dawes CJ (1986) Acclimation of the green alga Caulerpa racemosa var. uvifera to light. Bot Mar 29:533-537

Ryther JH (1956) The measurement of primary production. Limnol Oceanogr 1:72-84

Shapiro SS, Wilk MB (1965) An analysis of variance test for normality (complete samples). Biometrika 52:591-611

Soeder CJ, Hegewald E (1988) Scenedesmus. In: Borowitzka MA, Borowitzka LJ (eds) Microalgal biotechnology. Cambridge University Press, Cambridge, p 59-84

Steemann Nielsen E (1975) Marine photosynthesis with special emphasis on the ecological aspects. Elsevier, Amsterdam

Steinecke F (1925) Zur Polarität von Bryopsis. Bot Arch 12 : $97-118$

Strickland JDH (1960) Measuring the production of marine phytoplankton. J Fish Res Bd Can Bull 122

Terrados J, Ros JD (1991) Production dynamics in a macrophyte dominated ecosystem: the Mar Menor coastal lagoon (SE Spain). Oecol Aquat 10:255-270

Terrados J, Ros JD (1992) The influence of temperature on seasonal variation of Caulerpa prolifera (Forsskål) Lamouroux photosynthesis and respiration. J Exp Mar Biol Ecol 62:199-212

Tukey JW (1973) The problem of multiple comparisons. Princeton University, Princeton, NJ

Verlaque M, Fritayre P (1994) Modifications des communautés algales méditerranénnes en presence de l'algue envahissante Caulerpa taxifolia (Vahl) C. Agardh. Oceanol Acta 17:659-672

Villèle de X, Verlaque $M$ (1995) Changes and degradation in a Posidonia oceanica bed invaded by the introduced tropical alga Caulerpa taxifolia in the north western Mediterranean. Bot Mar 38:79-87

Webb WL, Newton M, Starr D (1974) Carbon dioxide exchange of Alnus rubra: a mathematical model. Oecologia 17:281-291

Wheeler PA, North BB, Littler MM, Stephens GC (1977) Uptake of glycine by natural phytoplankton communities. Limnol Oceanogr 22:900-910

Wheeler PA, North BB, Stephens GC (1974) Amino acid uptake by marine phytoplankters. Limnol Oceanogr 19:249-259 